\title{
Kikuchi-Fujimoto Disease Post COVID-19 Vaccination: Case Report and Review of Literature
}

\author{
Hui Min Tan ${ }^{1}$, Susan Swee-Shan Hue ${ }^{1}$, Aileen Wee ${ }^{1}$ and Kay Choong See ${ }^{2, *(1)}$ \\ 1 Department of Pathology, National University Hospital, Singapore 119074, Singapore; \\ hui_min_tan@nuhs.edu.sg (H.M.T.); swee_shan_hue@nuhs.edu.sg (S.S.-S.H.); patweea@nus.edu.sg (A.W.) \\ 2 Division of Respiratory and Critical Care Medicine, Department of Medicine, National University Hospital, \\ Singapore 119074, Singapore \\ * Correspondence: kay_choong_see@nuhs.edu.sg
}

Citation: Tan, H.M.; Hue, S.S.-S.; Wee, A.; See, K.C. Kikuchi-Fujimoto Disease Post COVID-19 Vaccination: Case Report and Review of Literature. Vaccines 2021, 9, 1251. https:// doi.org/10.3390/vaccines 9111251

Academic Editors: Karen Schreiber, Oliver Hendricks and Mathias W. Pletz

Received: 5 October 2021

Accepted: 27 October 2021

Published: 29 October 2021

Publisher's Note: MDPI stays neutral with regard to jurisdictional claims in published maps and institutional affiliations.

Copyright: (C) 2021 by the authors. Licensee MDPI, Basel, Switzerland. This article is an open access article distributed under the terms and conditions of the Creative Commons Attribution (CC BY) license (https:// creativecommons.org/licenses/by/ $4.0 /)$.

\begin{abstract}
With the rapid development of various coronavirus disease 2019 (COVID-19) vaccines in a bid to counter and contain the COVID-19 pandemic, unusual and uncommon side effects of COVID-19 vaccination have been increasingly reported in the literature. Ipsilateral lymphadenopathy is a fairly common side effect of vaccination of any kind, with its etiology most commonly related to reactive lymphadenopathy. However, Kikuchi-Fujimoto Disease (KFD) or necrotizing histiocytic lymphadenitis is rarely observed post-vaccination, with only one other case of KFD post COVID-19 vaccination reported to date. We report two more cases of KFD post COVID-19 vaccination in the Asian population, highlighting the clinical course and salient clinical, radiological and histologic findings. In addition, we provide a literature review of the existing cases of lymphadenopathy post COVID-19 vaccination with cytologic and/or histologic correlation.
\end{abstract}

Keywords: Kikuchi-Fujimoto disease; necrotizing histiocytic lymphadenitis; COVID-19; COVID-19 vaccine; lymphadenopathy

\section{Introduction}

More than a year after the coronavirus disease 2019 (COVID-19) pandemic emerged and rocked the world, many COVID-19 vaccines, ranging from messenger RNA (mRNA)based vaccines to inactivated virus vaccines, have been developed at unprecedented speed. As various countries ramp up their vaccination rates in a bid to contain the pandemic, unusual and uncommon side effects of COVID-19 vaccines have been increasingly discovered and reported.

Ipsilateral lymphadenopathy following vaccination is a well-described side effect and has been reported with several types of vaccines [1]. As part of the immune system, lymph nodes located at the drainage basin of the site of vaccination may undergo reactive lymphoid hyperplasia following stimulation by the antigens within the vaccine. In particular, post COVID-19 vaccination with mRNA-based vaccines, close to $15 \%$ of patients reported unilateral axillary lymphadenopathy [2]. For case reports that included some form of cytologic or histologic confirmation, most observed that the cause of lymphadenopathy was reactive in nature. In contrast, Kikuchi-Fujimoto Disease (KFD) or necrotizing histiocytic lymphadenitis is a very rare occurrence with only one published case report to date [3]. We describe two more patients from our institution who developed histologically confirmed KFD after receiving mRNA-based COVID-19 vaccine (Pfizer-BioNTech).

\section{Case Report}

The first patient (patient A) was an 18 year old Asian woman who was previously well and received her first vaccination dose on 4 June 2021 (Day 1). She developed fever and left axillary lymphadenopathy on Day 35, which persisted until presentation on Day 42 . The 
maximum temperature recorded was 40.5 degrees Celsius on Day 49. Transient leukopenia developed with a nadir on Day 52 (leukocyte count $3.26 \times 10^{9} / \mathrm{L}$, neutrophil count $1.37 \times 10^{9} / \mathrm{L}$ ). SARS-CoV-2 nucleocapsid antibody was not detected, and antibody titer against spike protein was $133.0 \mathrm{U} / \mathrm{mL}$. Anti-nuclear antibody titer was $<1: 80$, and anti-dsDNA titer was $10 \mathrm{IU} / \mathrm{mL}$ (normal $<100 \mathrm{IU} / \mathrm{mL}$ ). A computed tomography $(\mathrm{CT}) \mathrm{scan}$ of the neck and thorax performed on Day 49 demonstrated enlarged left supraclavicular, subpectoral and axillary lymph nodes measuring 1.7 to $2.0 \mathrm{~cm}$ (Figure 1). Ultrasound-guided left axillary lymph node core biopsy performed on Day 53 provided a diagnosis of necrotizing histiocytic lymphadenitis that was consistent with KFD (Figure 2). Ziehl-Neelsen (ZN) and Gomori methenamine silver (GMS) stains had been performed on the histology specimen, and no acid-fast bacilli or fungal organisms were identified, respectively.

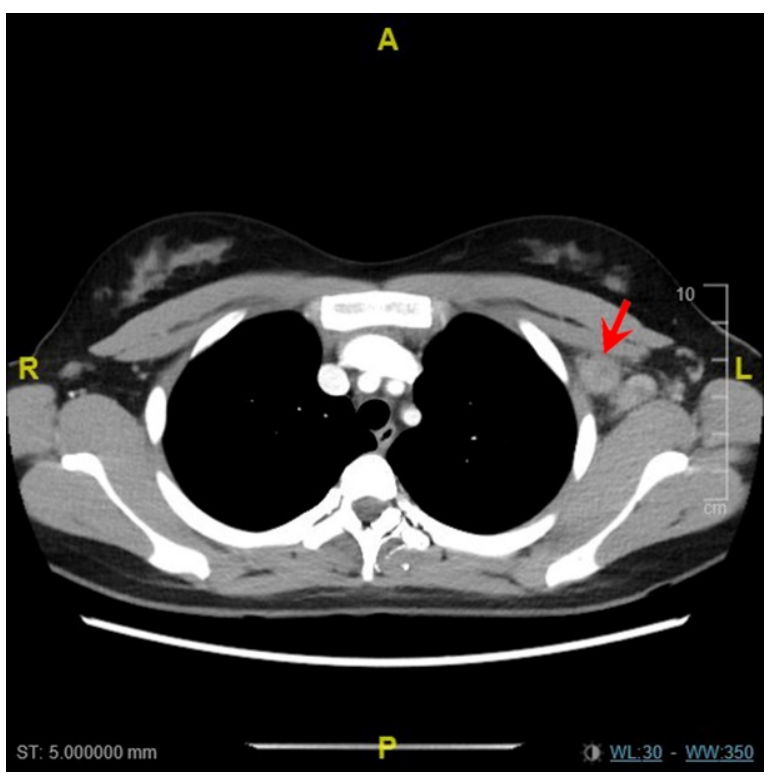

Figure 1. Computed tomography scan of patient A demonstrating enlarged left subpectoral and axillary lymph nodes (red arrow).

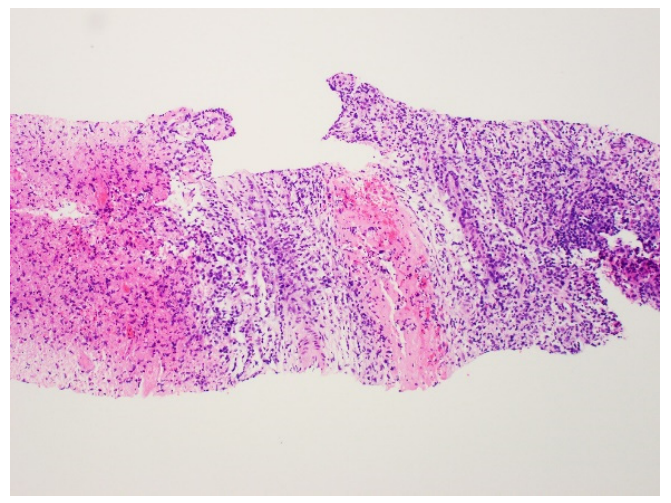

(a)

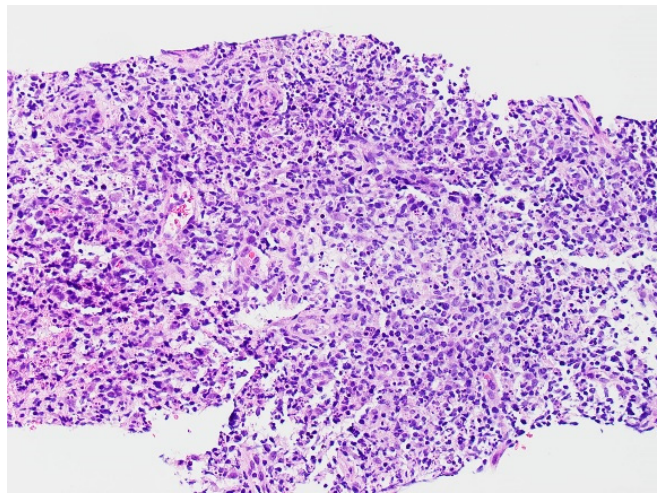

(b)

Figure 2. Histologic findings from core biopsy of left axillary lymph node from patient A. Formalinfixed, paraffin-embedded (FFPE) sections of the lymph node biopsy were stained with hematoxylin and eosin (H\&E). The lymph node showed confluent necrosis ( $\mathbf{a}$, left aspect) surrounded by a polymorphous population of lymphoid cells admixed with karyorrhectic debris and crescentic histiocytes (b).

The second patient (patient B) was a 34 year old Asian man with diabetes mellitus and hypertension who received his first vaccination dose on 3 July 2021 (Day 1). He developed fever and left axillary lymphadenopathy on Day 17, persisting until presentation on Day 
23. The maximum temperature recorded was 38.9 degrees Celsius on Day 26. Transient leukopenia developed with a nadir on Day 39 (leukocyte count $1.79 \times 10^{9} / \mathrm{L}$, neutrophil count $\left.1.05 \times 10^{9} / \mathrm{L}\right)$. SARS-CoV-2 nucleocapsid antibody was not detected, and antibody titer against spike protein was $6.9 \mathrm{U} / \mathrm{mL}$. Anti-nuclear antibody titer was 1:80, and antids-DNA titer was $<3 \mathrm{IU} / \mathrm{mL}$. A CT scan of the thorax, abdomen and pelvis performed on Day 27 demonstrated enlarged left axillary lymph nodes measuring up to $3.2 \mathrm{~cm}$ (Figure 3). Ultrasound-guided left axillary lymph node core biopsy performed on Day 33 provided a diagnosis of histiocytic lymphadenitis that was consistent with KFD (Figure 4). ZN and GMS stains had been performed on the histology specimen, and no acid-fast bacilli or fungal organisms were identified, respectively.

In both cases, COVID-19 ribonucleic acid (RNA) polymerase chain reaction (PCR), viral testing (human immunodeficiency virus antibody, Epstein-Barr virus IgM, cytomegalovirus IgM, toxoplasma IgM, dengue IgM, hepatitis B surface antigen and anti-hepatitis C antibody) and blood cultures were negative. Peripheral blood film did not show any blasts or atypical lymphocytes. The clinical course was marked by high fever and significant ipsilateral lymphadenopathy developing 2-5 weeks after vaccination and transient leukopenia developing 4-7 weeks after vaccination. The fever did not respond to paracetamol. Rather, a non-steroidal anti-inflammatory agent (ibuprofen) resulted in rapid and complete resolution of fever and lymphadenopathy over several days, with patient A's symptoms resolving by Day 58 and patient B's symptoms resolving by Day 38.

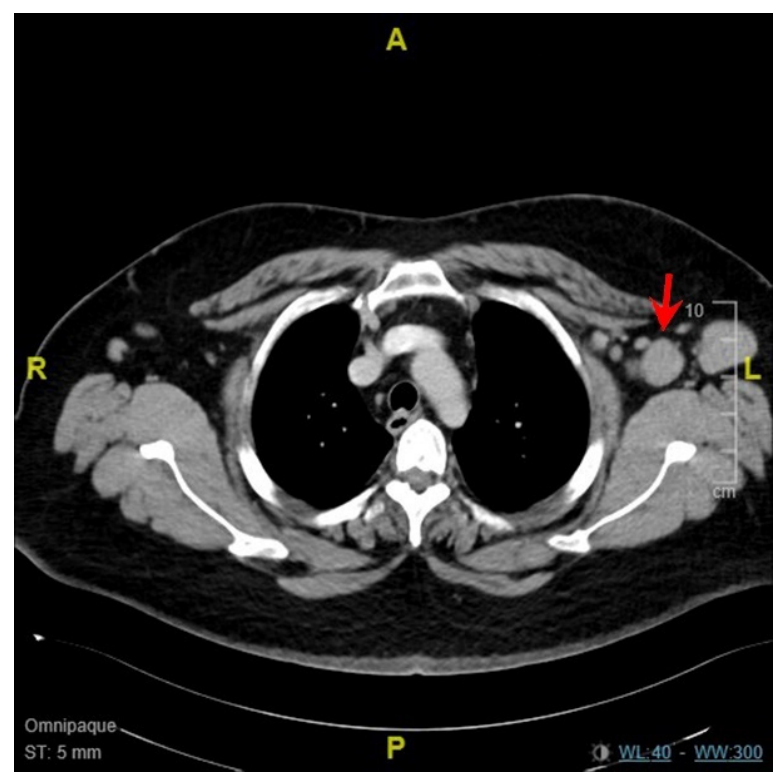

Figure 3. Computed tomography scan of patient B demonstrating enlarged left axillary lymph nodes (red arrow). 


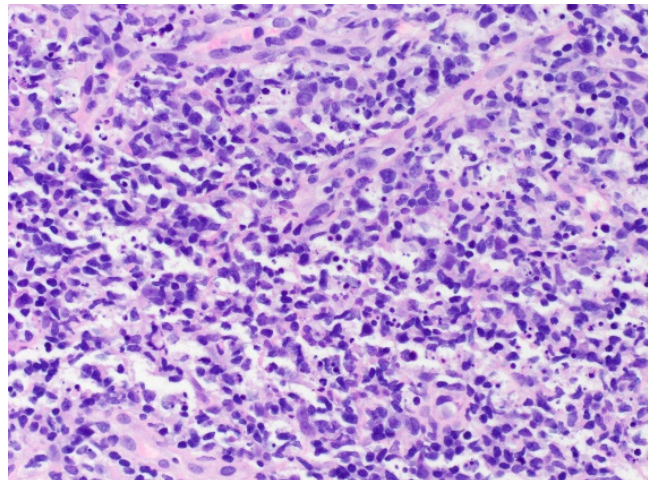

(a)

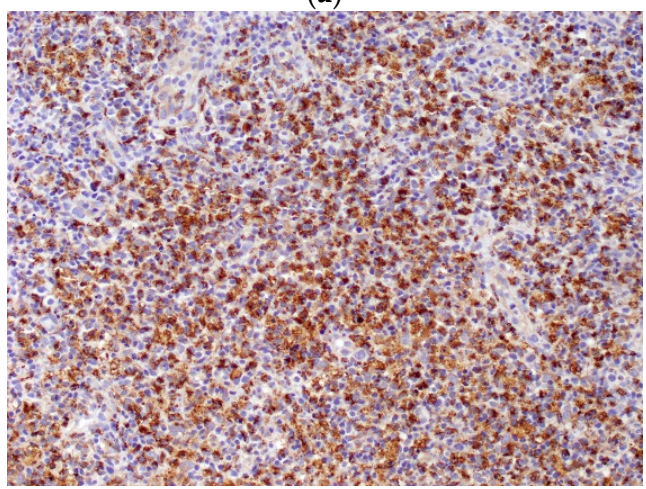

(c)

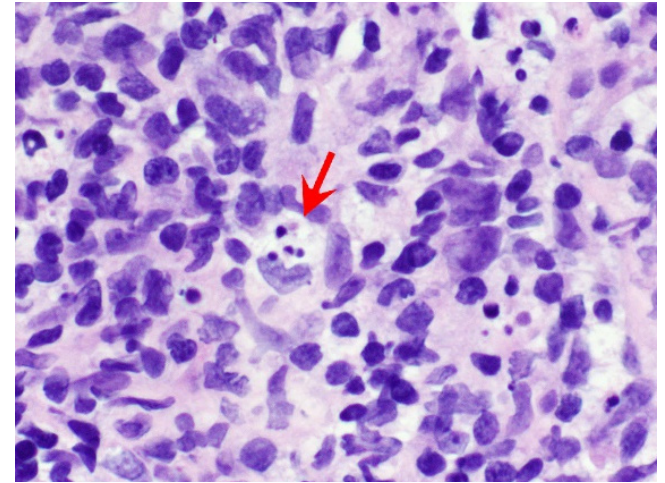

(b)

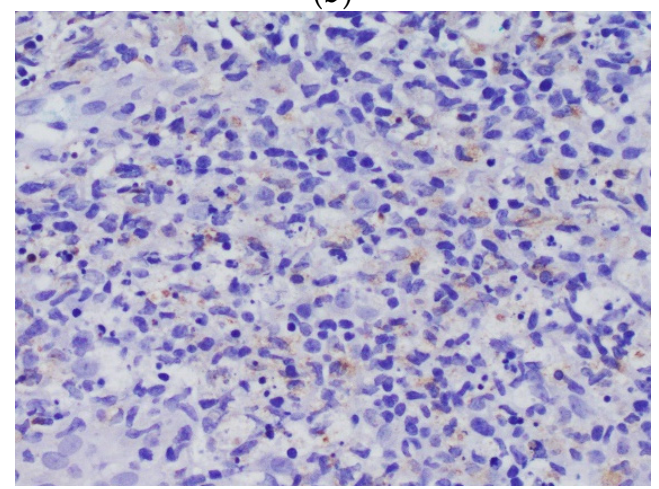

(d)

Figure 4. Histologic findings from core biopsy of left axillary lymph node from patient B. FFPE sections of the lymph node biopsy were stained with H\&E. (a) The lymph node showed numerous histiocytes, including some with crescentic morphology (b, red arrow), admixed with karyorrhectic debris, plasmacytoid monocytes and small lymphocytes. Immuno-peroxidase staining for CD68 (c) highlighted the histiocytes, which also showed focal expression of myeloperoxidase (MPO) (d).

\section{Discussion}

KFD is an uncommon but benign cause of lymphadenopathy. First described in the 1970s, it is more commonly observed in the Asian population and usually affects young adults. Patients typically present tender lymphadenopathy affecting the cervical (most common), axillary and/or supraclavicular lymph nodes, as well as fever. Other systemic symptoms may also be present, rendering KFD a great mimicker of various infectious, autoimmune or even neoplastic conditions. While KFD has a self-limiting course and treatment is mainly symptomatic in nature, the exact etiology remains uncertain with postulations mainly related to some form of exaggerated T-cell mediated immune response to antigens [4-6].

KFD very uncommonly occurs following vaccination, with only rare reports in the literature describing its occurrence after influenza vaccination [7], human papillomavirus vaccination and Japanese encephalitis virus vaccination [8]. A literature search yielded only one case report of KFD following COVID-19 vaccination at the time of writing [3], with many other papers describing cytologic or histologic findings of reactive follicular hyperplasia or reactive lymphadenopathy [9-14]. Table 1 details the key features of published cases of lymphadenopathy post COVID-19 vaccination, which also had cytologic and/or histologic follow-up. 
Table 1. Key features of cases of lymphadenopathy post COVID-19 vaccination with cytologic and/or histologic follow-up.

\begin{tabular}{|c|c|c|c|c|c|c|c|}
\hline Author & Age & Gender & Vaccine Received & $\begin{array}{c}\text { Interval between } \\
\text { Vaccination and LAD } \\
\text { or First Symptom }\end{array}$ & Site(s) of LAD * & Type of Sampling ${ }^{+}$ & Diagnosis \\
\hline Our case, patient A & 18 & Female & $\begin{array}{l}\text { Pfizer- } \\
\text { BioNTech }\end{array}$ & 35 days & $\begin{array}{c}\text { Supraclavicular, } \\
\text { subpectoral and } \\
\text { axillary }\end{array}$ & Core biopsy & $\mathrm{KFD}^{2}$ \\
\hline Our case, patient B & 34 & Male & $\begin{array}{c}\text { Pfizer- } \\
\text { BioNTech }\end{array}$ & 17 days & Axillary & Core biopsy & KFD \\
\hline $\begin{array}{c}\text { Soub et al. } \\
\text { (August 2021) [3] }\end{array}$ & 18 & Male & $\begin{array}{l}\text { Pfizer- } \\
\text { BioNTech }\end{array}$ & 10 days & $\begin{array}{c}\text { Supraclavicular, } \\
\text { cervical and axillary }\end{array}$ & Excision biopsy & KFD \\
\hline \multirow{5}{*}{$\begin{array}{l}\text { Özütemiz et al. } \\
\text { (February 2021) [9]; } \\
\text { oncologic patients }\end{array}$} & 32 & Female & $\begin{array}{c}\text { Pfizer- } \\
\text { BioNTech }\end{array}$ & 6 days & Axillary & Nil & - \\
\hline & 57 & Female & $\begin{array}{c}\text { Pfizer- } \\
\text { BioNTech }\end{array}$ & 5 days & Axillary & Nil & - \\
\hline & 41 & Male & $\begin{array}{l}\text { Pfizer- } \\
\text { BioNTech }\end{array}$ & 4 days & Axillary & Nil & - \\
\hline & 46 & Female & $\begin{array}{l}\text { Pfizer- } \\
\text { BioNTech }\end{array}$ & 15 days & $\begin{array}{c}\text { Axillary, } \\
\text { supraclavicular }\end{array}$ & Nil & Reactive lymph node \\
\hline & 38 & Female & $\begin{array}{l}\text { Pfizer- } \\
\text { BioNTech }\end{array}$ & 8 days & Axillary & Core biopsy & $\begin{array}{l}\text { Reactive follicular } \\
\text { hyperplasia }\end{array}$ \\
\hline \multirow{8}{*}{$\begin{array}{l}\text { Placke et al. } \\
\text { (June 2021) [11]; } \\
\text { patients with } \\
\text { previous } \\
\text { skin cancer }\end{array}$} & 54 & Female & CureVac & 30 days & Axillary & $\begin{array}{c}\text { Excision biopsy } \\
\text { (sentinel node) }\end{array}$ & $\begin{array}{l}\text { Lymphofollicular } \\
\text { hyperplasia }\end{array}$ \\
\hline & 28 & Female & $\begin{array}{c}\text { Pfizer- } \\
\text { BioNTech }\end{array}$ & 28 days & Axillary & $\begin{array}{l}\text { Excision biopsy } \\
\text { (selective) }\end{array}$ & Sarcoid-like reaction \\
\hline & 58 & Male & $\begin{array}{l}\text { Pfizer- } \\
\text { BioNTech }\end{array}$ & 7 days & Axillary & $\begin{array}{l}\text { Excision biopsy } \\
\text { (selective) }\end{array}$ & $\begin{array}{c}\text { Not mentioned, } \\
\text { but non-malignant }\end{array}$ \\
\hline & 77 & Male & $\begin{array}{c}\text { Pfizer- } \\
\text { BioNTech }\end{array}$ & 11 days & Axillary & $\begin{array}{l}\text { Excision biopsy } \\
\text { (sentinel node) }\end{array}$ & $\begin{array}{l}\text { Not mentioned, } \\
\text { but non-malignant }\end{array}$ \\
\hline & 91 & Male & $\begin{array}{l}\text { Pfizer- } \\
\text { BioNTech }\end{array}$ & 16 days & Axillary & $\begin{array}{l}\text { Excision biopsy } \\
\text { (sentinel node) }\end{array}$ & $\begin{array}{c}\text { Not mentioned, } \\
\text { but non-malignant }\end{array}$ \\
\hline & 44 & Male & $\begin{array}{l}\text { Pfizer- } \\
\text { BioNTech }\end{array}$ & 15 days & Axillary & $\begin{array}{l}\text { Excision biopsy } \\
\text { (sentinel node) }\end{array}$ & $\begin{array}{c}\text { Not mentioned, } \\
\text { but non-malignant }\end{array}$ \\
\hline & 43 & Female & $\begin{array}{l}\text { Pfizer- } \\
\text { BioNTech }\end{array}$ & 50 days & Axillary & Lymphadenectomy & $\begin{array}{l}\text { Not mentioned, } \\
\text { but non-malignant }\end{array}$ \\
\hline & 84 & Female & $\begin{array}{l}\text { Pfizer- } \\
\text { BioNTech }\end{array}$ & 12 days & Axillary & $\begin{array}{l}\text { Excision biopsy } \\
\text { (sentinel node) }\end{array}$ & $\begin{array}{c}\text { Not mentioned, } \\
\text { but non-malignant }\end{array}$ \\
\hline
\end{tabular}


Table 1. Cont

\begin{tabular}{|c|c|c|c|c|c|c|c|}
\hline Author & Age & Gender & Vaccine Received & $\begin{array}{l}\text { Interval between } \\
\text { Vaccination and LAD } \\
\text { or First Symptom }\end{array}$ & Site(s) of LAD * & Type of Sampling ${ }^{\dagger}$ & Diagnosis \\
\hline \multirow{5}{*}{$\begin{array}{l}\text { Hagen et al. } \\
\text { (July 2021) [12] }\end{array}$} & 66 & Male & Moderna & 22 days & Axillary & FNAC $^{3}$ & \multirow{5}{*}{$\begin{array}{c}\text { Reactive } \\
\text { lymphadenopathy } \\
\text { Reactive } \\
\text { lymphadenopathy } \\
\text { Reactive } \\
\text { lymphadenopathy } \\
\text { Reactive } \\
\text { lymphadenopathy } \\
\text { Negative for } \\
\text { malignancy }\end{array}$} \\
\hline & 41 & Female & Moderna & 3 days & Infraclavicular & FNAC & \\
\hline & 47 & Female & $\begin{array}{c}\text { Pfizer- } \\
\text { BioNTech }\end{array}$ & 19 days & Supraclavicular & FNAC & \\
\hline & 47 & Female & Moderna & 8 days & Cervical & FNAC & \\
\hline & 52 & Male & $\begin{array}{c}\text { Pfizer- } \\
\text { BioNTech }\end{array}$ & 12 days & $\begin{array}{l}\text { Retroclavicular } \\
\text { (contralateral) }\end{array}$ & FNAC & \\
\hline $\begin{array}{l}\text { Tintle and Chen } \\
\text { (July 2021) [13] }\end{array}$ & 23 & Female & Moderna & 1 week & $\begin{array}{c}\text { Axillary, } \\
\text { intra-abdominal }\end{array}$ & Excision biopsy & $\begin{array}{l}\text { Lymphoid and } \\
\text { Langerhan cell } \\
\text { hyperplasia, } \\
\text { hemophagocytosis }\end{array}$ \\
\hline $\begin{array}{c}\text { Tan et al. } \\
\text { (August 2021) [14] }\end{array}$ & 34 & Male & $\begin{array}{c}\text { Pfizer- } \\
\text { BioNTech }\end{array}$ & 1 day & Supraclavicular & FNAC & $\begin{array}{c}\text { Reactive } \\
\text { lymphadenopathy }\end{array}$ \\
\hline
\end{tabular}

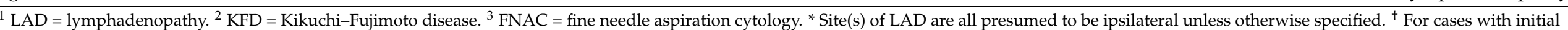

FNAC followed by tissue biopsy, only the latter is indicated. 
In the patients who developed reactive lymphadenopathy post COVID-19 vaccination, they usually had no symptoms or had only experienced painless enlargement of lymph node(s). On the contrary, the patients with KFD post COVID-19 vaccination had fever and other systemic manifestations. In addition, reactive lymphadenopathy post COVID-19 vaccination may occur as soon as the day after the vaccine was given, but KFD tended to occur in a more delayed setting, ranging from 10 to 35 days based on our two cases and the sole other published case.

Certain infectious lymphadenitis, autoimmune conditions (e.g., systemic lupus erythematosus in particular) and lymphoproliferative disorders may also give rise to similar or overlapping histomorphologic findings as KFD, and these have to be considered and excluded before a diagnosis of KFD is made. In our two cases, extensive clinical workup was performed to exclude infectious and autoimmune causes, and histology also confirmed the absence of lymphoproliferative disorders.

Being a self-limiting disease, KFD typically resolves within months. While there is no specific treatment for KFD, symptomatic treatment with analgesics is usually sufficient, with steroids sometimes being used in more severe or recurrent cases [5,6]. In our two cases as well as the other case reported in literature by Soub et al. [3], the patients' symptoms resolved within a month of onset, and treatment with analgesics proved to be effective for the relief of symptoms. For our two cases, non-steroidal anti-inflammatory drugs (NSAIDs), in particular, appeared to be more effective than paracetamol. Epidemiology-wise, our cases included young Asian adults, while the case reported by Soub et al. was a young Middle Eastern male.

We note that the patients who developed KFD post COVID-19 vaccination all received mRNA-based vaccines. Nonetheless, more data are needed to determine if KFD is an occurrence specific to mRNA-based vaccines only or if KFD could also occur in patients receiving other types of vaccines.

In addition, KFD can occur post or concurrent with COVID-19 infection [15,16]. While the ethnicity of the patients was not specifically mentioned in the available case reports, the patients were young (less than 20 years old), presented with prolonged fever and other systemic symptoms and one case mentioned rapid resolution of the symptoms within 7 days of commencing supportive treatment $[15,16]$. The clinical course of these cases was similar to that of KFD in general, as well as the cases of KFD post COVID-19 vaccination.

While the limited number of cases available renders it difficult to determine if the association of KFD and COVID-19 infection/vaccination is that of a causal relationship, KFD remains an important condition to consider when patients with recent COVID-19 vaccination or infection develop lymphadenopathy with other systemic symptoms.

\section{Conclusions}

KFD may rarely occur after COVID-19 vaccination, with patients usually presenting with lymphadenopathy, fever and other systemic symptoms more than a week after the vaccine dose was applied. The initial clinical presentation may be alarming and mimics infections, autoimmune conditions or even lymphoproliferative disorders, especially if the history of prior vaccination was not readily provided or considered. Fortunately, the disease runs a benign and self-limiting course with rapid resolution of symptoms after symptomatic and supportive treatment. It is, hence, important that clinicians recognize this potential condition that may occur after COVID-19 vaccination and to avoid excessive investigation and unnecessary treatment.

Author Contributions: Conceptualization, K.C.S.; methodology, K.C.S., H.M.T., S.S.-S.H. and A.W.; writing-original draft preparation, K.C.S. and H.M.T.; writing-review and editing, K.C.S., H.M.T., S.S.-S.H. and A.W.; supervision, K.C.S. All authors have read and agreed to the published version of the manuscript.

Funding: This research received no external funding.

Institutional Review Board Statement: Not applicable. 
Informed Consent Statement: Written informed consent has been obtained from both patients to publish this paper.

Data Availability Statement: Data sharing not applicable.

Conflicts of Interest: The authors declare no conflict of interest.

\section{References}

1. Hartsock, R.J. Postvaccinial lymphadenitis. Hyperplasia of lymphoid tissue that simulates malignant lymphomas. Cancer 1968, 21, 632-649. [CrossRef]

2. Lehman, C.D.; D'Alessandro, H.A.; Mendoza, D.P.; Succi, M.D.; Kambadakone, A.; Lamb, L.R. Unilateral Lymphadenopathy After COVID-19 Vaccination: A Practical Management Plan for Radiologists Across Specialties. J. Am. Coll. Radiol. 2021, 18, 843-852. [CrossRef] [PubMed]

3. Soub, H.A.; Ibrahim, W.; Maslamani, M.A.; AAli, G.; Ummer, W.; Abu-Dayeh, A. Kikuchi-Fujimoto disease following SARS CoV2 vaccination: Case report. IDCases 2021, 25, e01253. [CrossRef]

4. Asano, S.; Akaike, Y.; Jinnouchi, H.; Muramatsu, T.; Wakasa, H. Necrotizing lymphadenitis: A review of clinicopathological, immunohistochemical and ultrastructural studies. Hematol. Oncol. 1990, 8, 251-260. [CrossRef] [PubMed]

5. Bosch, X.; Guilabert, A.; Miquel, R.; Campo, E. Enigmatic Kikuchi-Fujimoto Disease: A Comprehensive Review. Am. J. Clin. Pathol. 2004, 122, 141-152. [CrossRef] [PubMed]

6. Perry, A.M.; Choi, S.M. Kikuchi-Fujimoto Disease: A Review. Arch. Pathol. Lab. Med. 2018, 142, 1341-1346. [CrossRef] [PubMed]

7. Podugu, A.; Kobe, M. Kikuchi-Fujimoto Disease (KFD): A Rare Cause of Fever and Lymphadenopathy Following Influenza Vaccination. Chest 2013, 144, 230A. [CrossRef]

8. Watanabe, T.; Hashidate, H.; Hirayama, Y.; Iinuma, Y. Kikuchi-Fujimoto disease following vaccination against human papilloma virus infection and Japanese encephalitis. Eur. J. Pediatr. 2012, 171, 1409-1411. [CrossRef] [PubMed]

9. Özütemiz, C.; Krystosek, L.A.; Church, A.L.; Chauhan, A.; Ellermann, J.M.; Domingo-Musibay, E.; Steinberger, D. Lymphadenopathy in COVID-19 Vaccine Recipients: Diagnostic Dilemma in Oncologic Patients. Radiology 2021, 300, E296-E300. [CrossRef] [PubMed]

10. Cardoso, F.; Reis, A.; Osório, C.; Scigliano, H.; Nora, M. A Case of Cervical Lymphadenopathy after Vaccination Against COVID-19. Cureus 2021. [CrossRef] [PubMed]

11. Placke, J.-M.; Reis, H.; Hadaschik, E.; Roesch, A.; Schadendorf, D.; Stoffels, I.; Klode, J. Coronavirus disease 2019 vaccine mimics lymph node metastases in patients undergoing skin cancer follow-up: A monocentre study. Eur. J. Cancer 2021, 154, 167-174. [CrossRef]

12. Hagen, C.; Nowack, M.; Messerli, M.; Saro, F.; Mangold, F.; Bode, P.K. Fine needle aspiration in COVID-19 vaccine-associated lymphadenopathy. Swiss Med. Wkly. 2021. [CrossRef]

13. Tintle, S.; Chen, M. Lymphadenopathy with florid lymphoid and Langerhans cell hyperplasia and hemophagocytosis mimicking lymphoma after COVID-19 mRNA vaccination. eJHaem 2021, jha2.265. [CrossRef]

14. Tan, N.J.H.; Tay, K.X.J.; Wong, S.B.J.; Nga, M.E. COVID-19 post-vaccination lymphadenopathy: Report of cytological findings from fine needle aspiration biopsy. Diagn. Cytopathol. 2021, dc.24863. [CrossRef] [PubMed]

15. Jaseb, K.; Nameh Goshay Fard, N.; Rezaei, N.; Sadeghian, S.; Sadeghian, S. COVID-19 in a case with Kikuchi-Fujimoto disease. Clin. Case Rep. 2021, 9, 1279-1282. [CrossRef]

16. Stimson, L.; Stitson, R.; Bahhadi-Hardo, M.; Renaudon-Smith, E. COVID-19 associated Kikuchi-Fujimoto disease. Br. J. Haematol. 2021, 192. [CrossRef] 